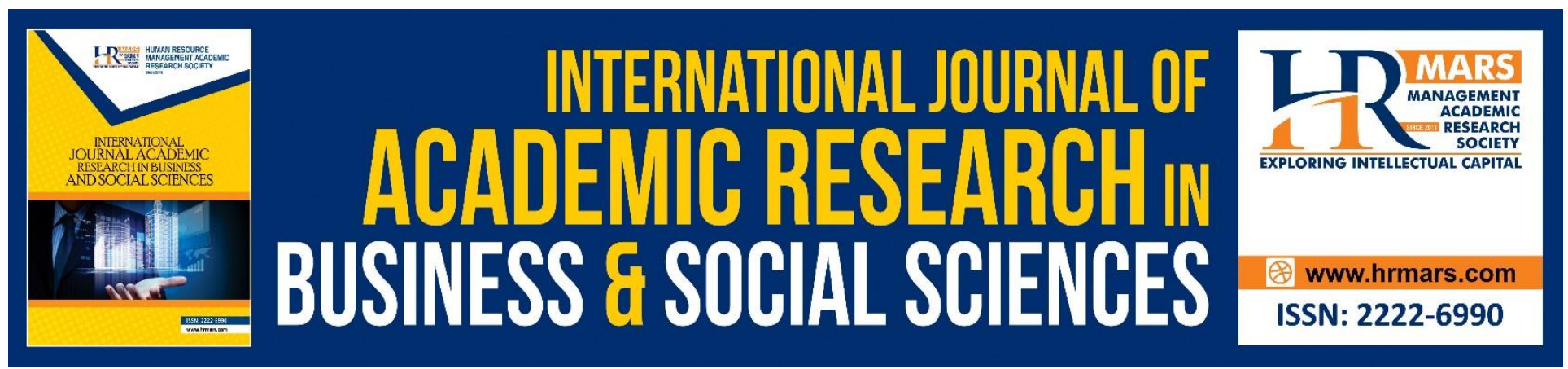

\title{
The Code of Conduct (Adab) for Rulers in Two Malay Masterpieces
}

\author{
Rahimah Hamdan, Siti Nor Harmiza Ibrahim
}

To Link this Article: http://dx.doi.org/10.6007/IJARBSS/v9-i5/5844

DOI: $10.6007 /$ IJARBSS/v9-i5/5844

Received: 12 Feb 2019, Revised: 17 March 2019, Accepted: 30 April 2019

Published Online: 03 May 2019

In-Text Citation: (Hamdan \& Ibrahim, 2019)

To Cite this Article: Hamdan, R., \& Ibrahim, S. N. H. (2019). The Code of Conduct (Adab) For Rulers in Two Malay Masterpieces. International Journal of Academic Research Business and Social Sciences, 9(5), 114-127.

\section{Copyright: (C) 2019 The Author(s)}

Published by Human Resource Management Academic Research Society (www.hrmars.com)

This article is published under the Creative Commons Attribution (CC BY 4.0) license. Anyone may reproduce, distribute, translate and create derivative works of this article (for both commercial and non-commercial purposes), subject to full attribution to the original publication and authors. The full terms of this license may be seen

at: http://creativecommons.org/licences/by/4.0/legalcode

Vol. 9, No. 5, 2019, Pg. 114 - 127

http://hrmars.com/index.php/pages/detail/IJARBSS

JOURNAL HOMEPAGE

Full Terms \& Conditions of access and use can be found at http://hrmars.com/index.php/pages/detail/publication-ethics 


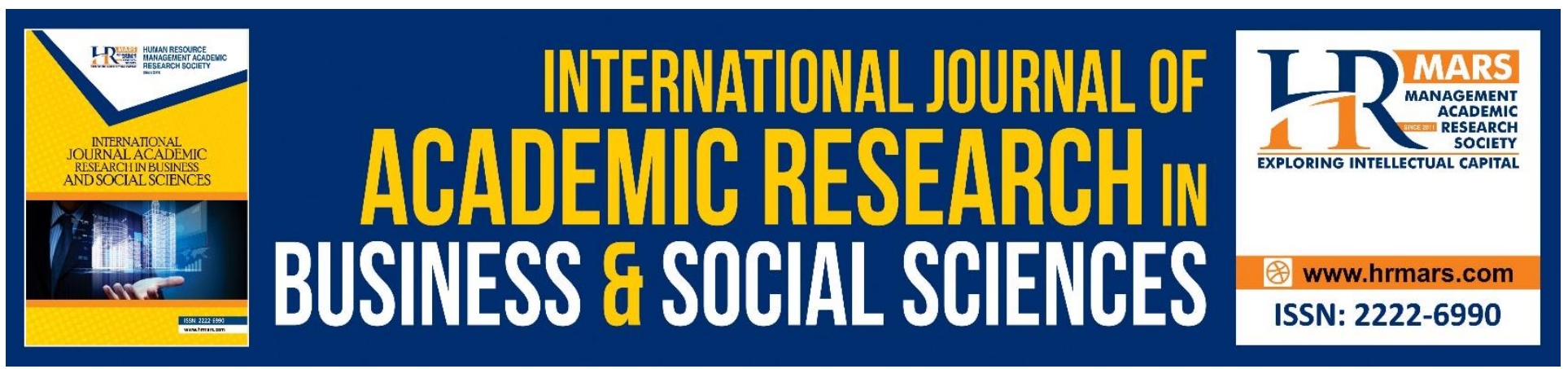

\title{
The Code of Conduct (Adab) For Rulers in Two Malay Masterpieces
}

\author{
Rahimah Hamdan and Siti Nor Harmiza Ibrahim \\ Department of Malay Language, Faculty of Modern Language and Communication, \\ Universiti Putra Malaysia, 43400 UPM Serdang, Selangor \\ Email: rahimahh@upm.edu.my
}

\begin{abstract}
The aim of this paper was to explain about the code of conduct ( $a d a b$ ) as described in the Malay literary masterpiece, the Taj Us Salatin (Mahkota Raja-Raja), and to compare it with the famous epic Malay text, the Hikayat Iskandar Zulkarnain. The Taj Us Salatin (Mahkota Raja-Raja), a well-known literary work on constitutionalism written by Bukhari Al-Jauhari, was used by the Malay rulers as a guidebook on governance, starting from the time of Sultan Alauddin Riayat Shah in Acheh in the 17th century until the time of Sultan Hussein Syah of the Johore-Singapore Sultanate in the 19th century. All the procedures of government were comprehensively recorded in this book by the author. As a result, a prominent figure, Iskandar Zulkarnain, who was both a great ruler and warrior, was said to be the first in a royal line of Malay sultans, as recorded in historiographic works. Hence, this noble figure was often highly esteemed in most of the literary works and, in fact, this manifestation was even assumed to validate the sovereignty of a kingly dynasty in the Malay World. The question is, were the guidelines for rulers, as recorded in the Taj Us Salatin, in line with the code of conduct (adab) for rulers and warriors in the epic Hikayat Iskandar Zulkarnain? Therefore, by doing a text analysis of the Taj Us Salatin (Mahkota Raja-Raja) and the Hikayat Iskandar Zulkarnain, this paper compared the connection and link in the characterisation of the code of conduct (adab) for rulers between both texts. This study makes an important contribution, especially in enhancing the contribution of the Malay masterpiece, the Taj Us Salatin (Mahkota Raja-Raja), as a constitutional literature containing highly valuable knowledge, and Iskandar Zulkarnain as a famous Malay ruler and warrior. In summary, the code of conduct ( $a d a b$ ) of a ruler was reflected in the stability and peace that prevailed in a country, so much so that this element was given serious emphasis in most of the genres of traditional Malay literature.
\end{abstract}

Keywords: Code of Conduct (Adab), Traditional, Masterpiece, Taj Us Salatin, Hikayat Iskandar Zulkarnain 
INTERNATIONAL JOURNAL OF ACADEMIC RESEARCH IN BUSINESS AND SOCIAL SCIENCES

Vol. 9, No. 5, May, 2019, E-ISSN: 2222-6990 @ 2019 HRMARS

\section{Introduction}

The civilization of a race is reflected in the literary works produced by scholars such as M. Khalid Taib, Noriah Taslim, Ismail Hamid and several others through literary works in the form of epics. This is reflected in their opinions that are more inclined to view epics through the lens of oral tradition as a source of useful information (Siti Hawa Haji Salleh, 2009: 117). This can also be seen in historical works and epics such as the Sejarah Melayu, Hikayat Aceh, Hikayat Merong Mahawangsa, Hikayat Iskandar Zulkarnain and so on that narrate the history of the rulers and their government, while the constitutional works, comprised of the Bustanus Salatin, Tajus Salatin (Mahkota Raja-Raja), Tahamarat al Muhimmah and so on, describe the guidelines in relation to the governance procedures for rulers and state dignitaries in the Malay World. Both these literary genres indicate various procedures in the code of conduct ( $a d a b)$ that can change or form a government, and they are pregnant with lessons. For instance, the Taj Us Salatin (Mahkota Raja-Raja) is filled with rules and guidelines. Hence, all these rules and guidelines were referred to in literary works to describe a government. For example, the Hikayat Iskandar Zulkarnain, describes the character of Raja Iskandar of Macedonia, who became a famous legend in the world. As explained in the Sejarah Melayu, Iskandar Zulkarnain started a line of Malay rulers through his marriage with the daughter of Raja Keling, Princess Syahrul Bariyah (A. Samad Ahmad, 2013: 6). In addition, there is also a legend that links the origins of the sultanate to the descendants of Iskandar Zulkarnain, as mentioned in the Hikayat Siak, Hikayat Acheh, Hikayat Banjar and the Misa Melayu. This clearly proves that Raja Iskandar was such a renowned figure that he was upheld as a famous ruler and was linked to the Malay royal lineage.

The Hikayat Iskandar Zulkarnain portrays a world-famous figure, as found in the Al-Quran at the end of the surah al-Kahfi. This person was special because he was the only ruler who was also a warrior. He was a great conqueror, and was even known to have started the lineage of Malay rulers. The Hikayat Iskandar Zulkarnain attracted the interest of various parties, especially scholars such as R. J. Wilkinson, who studied this text and published it in 1808 and 1902 (Khalid Hussain, 2015: xxv). In addition, other scholars such as Halimah Hassan (2001), S. Othman Kelantan (2007) as well as Nor Asma Ab Aziz and Muhd Norizam Jamian (2016), discussed various aspects of this work concerning his reign, character and leadership. In this regard, no study was carried out to compare the epic, Hikayat Iskandar Zulkarnain, with other constitutional literature, especially the Taj Us Salatin (Mahkota Raja-Raja), or other genres in traditional Malay literature. However, several local and foreign scholars have studied and understand the governance guidelines in the Taj Us Salatin (Mahkota Raja-Raja) such as Marrison (1955), Khalid M. Hussin (1966), Brakel (1970), Fatimah Embong (1982), Mohd. Aris Othman (1983), Siti Hawa Haji Salleh (1992 and 2010), Braginsky (1993 and 2000), Jelani Harun (2006 and 2009), Khalif Muammar A. Harris (2011), Shah Rul Anuar (2012) and Rahimah Hamdan and Arbaie Sujud (2017).

With this as a starting point, this study will focus on the aspect of the 'adab' for rulers with two main objectives in mind, namely, to describe the code of conduct (adab) for Malay rulers as contained in the Taj Us Salatin (Mahkota Raja-Raja) and to compare it with the code of conduct (adab) for rulers and warriors in the famous traditional Malay literary work, the Hikayat Iskandar Zulkarnain. This work was selected because it is related to the leadership of Iskandar Zulkarnain, who was praised as an 
INTERNATIONAL JOURNAL OF ACADEMIC RESEARCH IN BUSINESS AND SOCIAL SCIENCES

Vol. 9, No. 5, May, 2019, E-ISSN: 2222-6990 @ 2019 HRMARS

outstanding ruler. At the same time, a comparison was made of the 'adab' for rulers by using the guidelines to governance in the Taj Us Salatin (Mahkota Raja-Raja). Indirectly, this study can also unravel the character of Iskandar Zulkarnain, who was praised as a ruler and warrior and even as a religious leader, until his name became a byword in the world of Malay literature.

\section{Taj Us Salatin: The Book on Governance}

The Taj Us Salatin (Mahkota Raja-Raja) is a book on governance procedures that is found in traditional Malay literature. This guidebook for rulers discusses in detail the duties of rulers in matters of administration. It was written by Bukhari Al-Jauhari in Acheh in 1603. Taj Us is an Arabic word that means 'Crown', while al-salatin carries the meaning of 'Rulers'. Thus, when put together, they become Taj Us Salatin, i.e. Crown of Rulers (Ismail Hamid, 1987: 217). This work was introduced because it contains guidelines and lessons for rulers, especially for the Malay rulers who were governing and administrating the respective states. In fact, according to Ismail Hamid (1987: 217), the Taj Us Salatin (Mahkota Raja-Raja) was famous in the past as a copy was published in Jakarta in 1901 and it was used as reference by the rulers of Jawa in governing their country. This proved that this constitutional book was valid and useful as a reference book.

The Taj Us Salatin (Mahkota Raja-Raja), which was written by Bukhari Al-Jauhari, lists 24 clauses that are directed specifically at rulers in dealing with various aspects of humanity. In fact, this guidebook for rulers is Islamic in nature, where the author emphasizes the aspects of belief and faith in Allah S.W.T based on the perception of life as contained in the Al-Quran and Hadis. The author also emphasizes the aspect of leadership by the Prophet S.A.W. as a model and guide for rulers. This was because the ruler was not only the government but was also the religious leader entrusted with the task of executing the commands of Allah as an ordinary human being. Accordingly, the author mentions 10 characteristics that must be possessed by a ruler. For example, a ruler must be fair in carrying out his duties, knowledgeable, comely in appearance, generous, courageous, manly, and so on.

In general, the code of conduct (adab) for rulers in the Taj Us Salatin (Mahkota Raja-Raja) covers five aspects, namely:

i) The fact that humans are created beings and have an agreement with their Creator.

ii) The character of a ruler and administrative procedures.

iii) The responsibilities of dignitaries.

iv) The relationship between the people and the rulers and dignitaries.

v) The importance of knowledge.

Hence, this study only focused on the second aspect, namely the character of a ruler and administrative procedures, which covered 24 clauses as framed by Bukhari Al-Jauhari. Of the 24 clauses, only 9 clauses referred to the rules and procedures of governance and were used as 'yardsticks' in comparing the rules of governance in the Taj Us Salatin (Mahkota Raja-Raja) with the character of the ruler, Raja Iskandar, as described in the literary work, Hikayat Iskandar Zulkarnain. 
INTERNATIONAL JOURNAL OF ACADEMIC RESEARCH IN BUSINESS AND SOCIAL SCIENCES

Vol. 9, No. 5, May, 2019, E-ISSN: 2222-6990 @ 2019 HRMARS

\section{Definition of 'Adab'}

According to the Kamus Edisi Dewan (2007: 7), 'adab' is defined as manners and a refined way of speaking or the elegant behaviour of a person. 'Adab' also refers to the identification and recognition of a place, position and the exact and true situation in life, and self-discipline in order to participate positively (Al Attas, 1993: 129). Meanwhile, according to Mohd Zaidi Ismail and Wan Suhaimi Wan Abdullah (2012: 45), who quoted Al-Attas' opinion, 'adab' is the introduction to the fact that knowledge and events are arranged in an orderly manner according to rank and dignity. 'Adab' is also related to the actual position of a person with regard to that fact based on his physical and mental potential, intellect and spirit. In other words, from the Islamic perspective, 'adab' is defined as the efforts of human beings to bring about a proper and correct order and organisation as taught by Islam since its inception by recognising God and exalting the Prophet Muhammad S.A.W. as His messenger. Accordingly, Al-Attas (2001) explained that literature plays a role in cultivating 'adab' to produce commendable human beings who are well-balanced spiritually and physically. In fact, there is a clear similarity with the concept of al-adabi that literature that comes from a subtle soul is aimed at teaching and nurturing pure values in the hearts of its audience (Shafie, 1996: 118-151). The wide meaning accorded to 'adab' clearly provides some guidance to the literary genre of constitutionalism, which embraces the most important features of traditional literature. As explained by Jelani Harun (2003: 4) in 'Mirror for Rules', the role of constitutional literature is to mould the minds and thinking of the people with regard to moral practices, values, courtesy, customs and so on. Among the works that are included in this 'mirror' classification are the Taj Us Salatin (Mahkota Raja-Raja), which was used as a source of reference by the government.

Comparison of the Code of Conduct (Adab) For Governance in the Taj Us Salatin (Mahkota Raja-Raja) and Hikayat Iskandar Zulkarnain

The king or ruler certainly possesses unparalleled privileges to be appointed the 'shadow of god'. According to Jelani Harun (2006: 309), the sanctity of rulers is no longer being glorified through the myths of gods but is firmly embedded as part of the faith of humans in God. A ruler regarded as the shadow of God in the world and, in that sense, he is to implement a form of administration and government. This concept also places the ruler in the highest position. The elevation and sacredness of the ruler's position have been reinforced with quotes from several surahs in the Al-Quran (i.e. surah An-Nisa: 59; surah Al-Nur: 51 and surah Al-Anbiya: 73). In looking at the essence of those surahs, it was found that the surah An-Nisa is more about the obedience of the people towards those in authority, as follows:

"O all ye who believe, obey Allah and obey the Messenger of Allah and the "Ulil Amri" (those in authority) among you. Then, if you oppose (dispute) any matter, you should return to the book of Allah."

(Surah-An Nisa, verse 59)

This obviously justifies the elevation of the dignity of a ruler as the government. In fact, the people should show their respect by submitting to and obeying him. It is only fitting that the people should glorify and serve their ruler as the one who holds the reins of government, as explained by Allah S.W.T. The author of the Hikayat Iskandar Zulkarnain introduced a prominent government figure. This story is a Malay epic that has been adapted from Arab-Persian literature. The Hikayat Iskandar 
Zulkarnain is also comparable with Middle Eastern epics that are familiar to the Malays, namely, the Hikayat Amir Hamzah and Hikayat Ali Hanafiyah. According to Khalid Hussain (2015: xxvii), it can no longer be denied that the Hikayat Iskandar Zulkarnain is one of the most important legends and is comparable with other great literary works in the world such as Homer's The Illiad and The Odyssey. This is because Iskandar's character and personality were such that he deserves to be given the same recognition as other world-famous figures.

The Hikayat Iskandar Zulkarnain begins with a narration of the genealogy and birth of Raja Iskandar, the son of King Darab Rumi of Persia and Princess Safiya Arqiya. He is described as having a perfect character and his appearance was comely. He was very wise and studied under a leading scholar named Aristotle. Raja Iskandar also inherited his father's skill with weapons, especially in archery and javelin-throwing. Raja Iskandar then ascended the throne on the death of his grandfather, and he united the Roman and Persian governments after his younger brother, Raja Dara, who was ruling Persia, died in a civil war (Khalid Hussain. 2015: 54). Raja Iskandar's success in defeating his younger brother, Raja Dara, caused him to forget his roots and to succumb to the devil's temptations. The devil, who appeared to him as an old man, incited Raja Iskandar to the extent that he stopped worshipping Allah S.W.T (Khalid Hussain, 2015: 57). Hence, the Prophet Khindir appeared as a messenger sent by Allah to lead Raja Iskandar out from his perversity and ignorance. Finally, the advice and efforts of the Prophet Khindir bore fruit when Raja Iskandar repented and returned to his religion. After that, Raja Iskandar embraced the religion of the Prophet Ibrahim and was determined to spread Islam to the disbelieving and pagan countries. Among the territories he explored were Constantinople, Andalas, Rumiyar al-Akhbar, Egypt, Habsyi, China, Makkah and Madinah. Raja Iskandar was accompanied on his mission to Islamize those states and to spread the Islamic religion by the Prophet Khindir, who acted as his guardian and adviser. The character and leadership of Raja Iskandar indicated the positive qualities that should be possessed by a ruler. This was because Raja Iskandar was not a ruler who just remained in the palace and governed in one country alone, but he was a great ruler who was willing to go out of the palace and to explore all corners of the world to spread the teachings of Islam. This study attempted to prove that the legend of Raja Iskandar is the only traditional Malay literary work that is related to the code of conduct (adab) for rulers, as found in the guidelines contained in the Taj Us Salatin (Mahkota Raja-Raja) as well as compared to the behaviour and personality of Raja Iskandar Zulkarnain

i) The code of conduct (adab) for rulers concerning fairness

An administration or government will not collapse if it is governed justly and equitably. The Al-Quran explains the importance of fairness in dealing with human beings in order to ensure justice in all aspects of life. For example, it is stated in surah Al-Nah

"Verily, Allah commands that justice and good deeds should prevail, and aid must be offered to one's kinsmen; and the commission of despicable and unjust deeds are forbidden ...."

(Surah Al-Nahl, verse 90)

This clearly proves that in Islam, the concept of justice is not confined to the question of the government passing sentence but it covers everything that has to do with the people. This is so because in order to be a good ruler, the king should practise justice in all his administrative dealings 
INTERNATIONAL JOURNAL OF ACADEMIC RESEARCH IN BUSINESS AND SOCIAL SCIENCES Vol. 9, No. 5, May, 2019, E-ISSN: 2222-6990 @ 2019 HRMARS

(Jelani Harun, 2003: 124). The Taj Us Salatin (Mahkota Raja-Raja) outlines several clauses concerning the need for a ruler to be just. Among the clauses that touch on the quality of justice in a ruler are clauses 6, 7, 8, 9 and 17, as shown in Table 1.

Clause 6 : A just ruler comes under the protection of Arash in the sight of Allah

Clause 7 : Implementation of a just punishment

Clause 8 : A ruler who is just and understands and protects the people will bring prosperity to the country

Clause 9 : The people suffer at the hands of an unjust ruler

Clause 17 : The actions of a just ruler, who is not controlled by lust

Table 1: Clauses about justice

All the above clauses touch on the need for a ruler to be just, such as the 6th clause, which speaks about a just ruler being under the protection of Arash in the sight of Allah, and clause 7 about the implementation of a just punishment. Meanwhile, clause 8 relates that a ruler who is just and understands and protects the people will bring prosperity to the country. In fact, the 9th clause states that the people suffer at the hands of an unjust ruler. Subsequently, the last clause, i.e. the 17th clause, speaks about the actions of a just ruler, who does not allow himself to be controlled by lust. An examination of the Hikayat Iskandar Zulkarnain revealed that Raja Iskandar became a ruler who was able to successfully deal with incidents involving his life. For example, there was an incident where Raja Iskandar was poisoned by Naqfanus, a servant who prepared the food and drinks that were served to Raja Iskandar. Even though Raja Iskandar knew that the food served to him was poisoned, he did not immediately mete out punishment. On the contrary, Raja Iskandar investigated the incident and discovered that Naqfanus was indeed guilty and only then was he was sentenced for his intention to commit murder. This was because the act of murder is a vile act and anyone who commits the sin of murder will not be forgiven. This proves that Raja Iskandar was a just ruler who investigated first and did not hastily pass a sentence, as stated in the following excerpt:

'Then, Raja Iskandar said, "It is our duty to try him. He has been handed over to me. It is best to be careful, because I placed my life in his hands, and even so, he betrayed me." Then, the Prophet Khindir replied, "The king is silent, so it is obvious that he was sent to do the job." Thus, the Prophet Khindir withdrew from passing sentence. So, he asked that Naqfanus be brought before the judge. The judge then knew that the king was aware of the act to poison him.' 
(Hikayat Iskandar Zulkarnain. 2015: 72)

The code of conduct (adab) for rulers concerning knowledge

According to Al-Attas (2001: 51), science is a process or movement to acquire knowledge, and refers to the character of a living being that desires to know what it does not know. In fact, a person who is highly knowledgeable is held in high regard and becomes an icon in the society. This can be seen in traditional Malay literature, especially through the remarkable births of princes, who were equipped with knowledge of the various sciences, unparalleled heroism, a handsome appearance and splendid manners (Jelani Harun, 2003: 197). This proves that every ruler needs to be highly knowledgeable if he is to handle the administration of the country and ensure the quality of his government. The Taj Us Salatin (Mahkota Raja-Raja) emphasizes several clauses in the code of conduct (adab) for rulers, where knowledge is needed to ensure the smooth running of the government, namely in clauses 5 , 7 and 8 in Table 2:

\section{Clause 5 : The king is knowledgeable}

Clause 7 : A knowledgeable king

Clause 8 : About knowledgeable persons who are esteemed

Table 2: Clauses about knowledgeable kings

There are three clauses concerning this. Clause 5 stipulates that it is necessary for a king to be knowledgeable and to have friends who are knowledgeable. Meanwhile, the 7th clause describes the need for a ruler to have knowledge in order to be able to differentiate between good and bad. Next, clause 8 speaks a lot about how a person who possesses knowledge is esteemed and respected.

In examining the Hikayat Iskandar Zulkarnain, it was discovered that Raja Iskandar was a ruler who clearly possessed knowledge. For example, Raja Iskandar was not only very powerful and held a high position, but he also knew a lot about the religion. Because of his deep interest in religious knowledge, Raja Iskandar studied under the Prophet Khindir. This could be seen in the passage below, where Raja Iskandar's desire to acquire knowledge made him a ruler who was admired by many:

"According to legend, Raja Iskandar pledged to be with the Prophet Khindir for forty days to acquire all the knowledge contained in the religion of the Prophet Ibrahim. Raja Iskandar would only leave the Prophet Khindir when he understood him. Then, the revelation came to the Prophet Khindir that he was to remain with Raja Iskandar and tell him of all the work that Allah had prepared for him."

(Hikayat Iskandar Zulkarnain. 2015: 68)

The above excerpt clearly shows that a ruler or leader should equip himself with all forms of knowledge. Raja Iskandar was not only wise in religious matters, but he also knew the art of judging character, possessed knowledge of languages and so on. This shows that in order to run a 
INTERNATIONAL JOURNAL OF ACADEMIC RESEARCH IN BUSINESS AND SOCIAL SCIENCES Vol. 9, No. 5, May, 2019, E-ISSN: 2222-6990 @ 2019 HRMARS

government, a ruler has not only to be responsible for himself, but for all the people. A wise ruler will use his knowledge to lead his people and country well.

The code of conduct (adab) for rulers as messengers

Every human being is born into this world to be a servant and a religious leader. His duty as a servant is to devote himself to Allah S.W.T, while his duty as a religious leader is to lead mankind and to rule the world by means of the best administration, as explained in the Al-Quran through surah Al-Ar'raf. This verse also acknowledges the relationship between the human spirit and its Creator before it is born into the world. This proves that man is born into the world with the duties and responsibilities of a servant and religious leader, as stated in verse 172 of the surah Al-Ar'raf, which means:

And remember when your God brought forth from the seed (backbone) of Adam his descendants and Allah witnessed to their souls, saying "Am I not your God?" They replied, "Yes, we testify (You are our God)." This was done so that on the Day of Judgment you will not say, "Indeed, we were not aware of this."

(Surah Ar'raf, verse 172)

This was also mentioned by Bukhari Al-Jauhari, the author of the Taj Us Salatin (Mahkota Raja-Raja), who stated that the king is a religious leader (Khalid Hussain, 1966: 204). This concept is closely related to the idea of the king being a religious leader or shadow of God (Zilullahi) in the world. The king is not only the administrator of a government, but he is also a messenger of truth to his people. For example, the king must uphold the religious laws and administer his country according to the AlQuran and Sunnah. This was in line with the opinion of Mohd Taufik Abdullah (1993: 43) that a king must always remember his relationship to Allah S.W.T and all His creation. The author of Hikayat Iskandar Zulkarnain highlighted the code of conduct (adab) for rulers as messengers through the character of Raja Iskandar. In fact, clause 12 of the guidebook for rulers, i.e. the Taj Us Salatin (Mahkota Raja-Raja), talks about the role of a messenger, and touches on the story of Iskandar Zulkarnain who led a delegation to meet with Raja Darab. This matter was in relation to Raja Iskandar, who was regarded as a messenger to spread Islam and eliminate pagan religions from the face of the earth, as mentioned in the excerpt below:

"Truly, we were told." Then, the king said, "O my people, the one who is visiting us is a very great and fair king, who has been given the power by Allah to reign over everything in the world, and he is none other than Raja Iskandar, the son of Raja Darab."

(Hikayat Iskandar Zulkarnain, 2015: 131)

The above excerpt explains that the arrival of Raja Iskandar as a messenger and unifier of the races was anticipated by the people. This was because Raja Iskandar came bringing a pure religion that taught mankind to know their true Creator. As a result, Raja Iskandar succeeded in converting all the countries that he explored to Islam and managed to spread Islam to the rest of the world. 
The code of conduct (adab) for rulers concerning faith

Every human being must have faith in Allah S.W.T and fear Him as well as perform charitable works (Muhd Norizam et al., 2017: 69). This is because every person is measured according to his level of faith. A ruler must have a strong faith in order to rule his subjects. Jelani Harun (2003: 152) was of the opinion that a person of faith will try to advise his followers to do good and to avoid harmful practices. Doing good includes worshipping Allah through prayer, reading the Al-Quran and so on. To be a good leader, the individual must empower himself with enough religious knowledge to guide the people to the path of goodness. The emphasis on the faith of a ruler is recorded in the Taj Us Salatin (Mahkota Raja-Raja) in clauses 5, 6 and 7, as in Table 3 below:

\section{Clause 5 : A pious ruler}

\section{Clause 6 : A ruler who has been shown the true path}

\section{Clause 7 : A faithful and kind ruler}

Table 3: Clauses concerning a ruler of faith

Clause 5 is about a ruler who is pious, and clause 6 is about a ruler who has been shown the true path by Allah and is able to control his desires. Next, clause 7 is about a ruler who is faithful and kind. Overall, the book describes the code of conduct (adab) for a ruler, who has to have faith and carries out the commands of Allah S.W.T.

On reviewing the Hikayat Iskandar Zulkarnain, it was clear that it highlights the character of Raja Iskandar, who adhered to the code of conduct (adab) for a ruler who has faith. In fact, it further proves that Raja Iskandar was careful in his relationship with his Creator. Although in the eyes of the people he was a famous ruler and a mighty warrior, in the eyes of his Creator, he remained a sinful servant. Hence, he always submitted to the will of Allah and feared the punishment that would befall him should he disobey those commands. This was reflected in the following passage:

'Then, said Raja Iskandar, "Allah Almighty who created me will show me the true path. Hence, I have been sent to do all things. I should work to bring all men to serve him, so that no one should be left on Allah's earth, no one who passes by Him."

(Hikayat Iskandar Zulkarnain, 2015:65)

In fact, the faith of Raja Iskandar Zulkarnain was also evident from his constant gratitude for what he had. For example, Raja Iskandar prostrated himself in thanks to Allah S.W.T whenever he achieved any success. This proved the integrity of Raja Iskandar as a great leader with a strong faith. This was clearly evident in the excerpt below 
INTERNATIONAL JOURNAL OF ACADEMIC RESEARCH IN BUSINESS AND SOCIAL SCIENCES Vol. 9, No. 5, May, 2019, E-ISSN: 2222-6990 @ 2019 HRMARS

"Then, Raja Iskandar alighted from his horse. He bowed with his head to the ground before Allah. The Prophet Khindir said, "O king, it is fitting for us to bow to Allah for everything. We thank Him for his grace."

(Hikayat Iskandar Zulkarnain, 2015:184)

The code of conduct (adab) for rulers concerning generosity

The integrity and character of a ruler is not only evaluated externally but also internally. If a ruler has high morals and possesses good qualities (mahmudah), he will definitely not have to struggle as an administrator. Every human being must be generous. This coincides with the teachings of Islam that encourage the practice of helping one's fellow human beings since, as the saying goes, 'it is better to give than to receive.' This proves that the practice of giving is a praiseworthy characteristic that should be emulated. This was further reinforced by clause 5 in the Taj Us Salatin (Mahkota Raja-Raja) concerning the characteristics of a ruler, namely the fifth characteristic, which outlines the fact that the ruler must be generous and kind. In examining the Hikayat Iskandar Zulkarnain, the author introduced the character of Raja Iskandar as a generous ruler because of his action in assigning items to those who embraced Islam. His generous nature caused the number of followers of Islam to swell, and they praised his attitude. For example, the following excerpt shows that Raja Iskandar was a generous patron:

"Then, five dignitaries entered and sat in the place for nobles. The Prophet Khindir shook hands with Armu, and he sat down, as did all the rulers. Raja Iskandar awarded a person with a horse and a golden saddle. That ruler alone gave out six pieces of headgear, and those assembled there were given grand garments."

(Hikayat Iskandar Zulkarnain, 2015:119) Code of conduct (adab) regarding the relationship between a ruler and his people As a ruler, the king is also responsible for maintaining his relationship with the people. The ruler is the umbrella of the state, and his administration is the shelter that guards and takes care of the rights of the people (Rani, 2013: 90). Actually, there should not be a gap between the ruler and his people, but rather, they should have a good and close relationship with each other. This is because the government is needed and respected by the people, and the ruler should also respect the rights of his people. This is also closely related to the covenant in the Sejarah Melayu, namely, the agreement that was signed by Demang Lebar Daun, on behalf of the people, and Sang Sapurba, on behalf of the rulers. That agreement clearly explains that the people should obey the ruler, and the ruler should be fair to the people. The contents of the agreement showed that the ruler should take care of the welfare of the people, while the people should maintain their loyalty to the ruler (A. Samad Ahmad, 2013: 25). The guidebook for rulers, i.e. the Taj Us Salatin (Mahkota Raja-Raja), explains clearly about the code of conduct (adab) for rulers in relation to the people, where clause 9 is about a ruler passing sentence on his subjects, clause 17 is about a ruler being concerned about the fate of his people and taking care of their welfare, clause 20 is about a ruler being able to govern his people in fairness and with respect for the poor, and clause 21 speaks about the relationship between the ruler and those subjects who are unbelievers. 
It can be seen that all the clauses that touch on the relationship between the ruler and his subjects coincide with the Hikayat Iskandar Zulkarnain, which describes a prince who adheres to the code of conduct (adab) when relating with his subjects. As a ruler, Raja Iskandar constantly saw to the interests of his subjects as well as the people living in the countries he explored. Indeed, Raja Iskandar's actions to convert unbelievers to Islam was part of the code of conduct (adab) to safeguard the relationship between Muslims as all Muslims are to be regarded as brothers. This was evident in Raja Iskandar's determination to fight for Islam and to get rid of the pagan religions by approaching every citizen throughout the country, as stated in the following passage:

'On arriving at his camp, Raja Iskandar said, "O King Radhiah, I will soon be on my way. Go back to your family. Tell them to convert to Islam so that they can quickly be on their way. It is best that you return to your family. Tell them to convert to Islam so that they will know who wants and who does not want."

(Hikayat Iskandar Zulkarnain, 2015:140)

In fact, the character of Raja Iskandar was also evident by the way he was always in contact with pagans regardless of their religion. Wang Yong Bao (2009: 4) stated that Islam always guarantees freedom of religion for all people throughout the world. In fact, Allah S.W.T commands through the surah Al-Kafirun, verse 6:

"Your religion is for you and my religion is for me."

(Surah Al-Kafirun, verse 6)

This verse proves that there was no compulsion in one's choice of religion. In fact, in Islam, it is an obligation to treat the followers of other faiths well. This is intended to reflect the values of Islam in the eyes of the pagans. The Hikayat Iskandar Zulkarnanin clearly shows that Raja Iskandar was so concerned about the fate of the pagan warriors who fell and died on the battlefield. This shows that every ruler should have compassion for their fellowmen without discrimination and regardless of the rank or status of a person, as in the following passage:

'So, the Prophet Khindir said, "O king, give joy to your servant by claiming victory from Allah and helping him." Then, Raja Iskandar replied, "In the name of Allah, O beloved of Allah, I have no reason to be proud of myself, and I am not sad because of my commanders. I grieve because all those who fought against us have been killed. They died as pagans, and thus, they went to hell."'

\section{Conclusion}

(Hikayat Iskandar Zulkarnain, 2015:176)

On the whole, the Hikayat Iskandar Zulkarnain is an epic that gives a clear illustration of the character of Raja Iskandar. Raja Iskandar was an outstanding ruler and a great warrior in the eyes of the world, who spread Islam and engaged in a holy war on behalf of Allah S.W.T. This was evident from the fact that Iskandar Zulkarnain's name is so popular in the society and he is regarded as the first in the line of Malay rulers, where it is mentioned in the Sejarah Melayu that the rulers were descended from Raja Iskandar. In fact, Raja Iskandar was able to prove that a ruler should not stay in the palace, but should step out of the palace to get closer to the people. In addition, Raja Iskandar also proved that 
a ruler must possess good qualities (mahmudah) such as fairness, knowledge, faithfulness, and generosity, and he must carry out his responsibilities as a messenger and must be capable of maintaining a good relationship with the people. In accordance with the objectives of this study, it was found that the Taj Us Salatin (Mahkota Raja-Raja) was a guidebook for all the rulers in the Malay World in the 17th century as far back as the time of Acheh. This guidebook was also a medium of reference for all levels of government to ensure that the administration of the country is carried out properly and smoothly. This is because a just and wise government will give rise to a country that is politically, economically and socially peaceful. Thus, the character of Raja Iskandar in the Hikayat Iskandar Zulkarnain portrayed a behaviour that was positive and in accordance with the conditions set out in the Taj Us Salatin (Mahkota Raja-Raja), as could be seen from the attitude of Raja Iskandar, who glorified Islam in the eyes of the world. It clearly shows that a ruler needs to have an outstanding code of conduct (adab) and personality in order to lead and govern a country. Future research regarding Raja Iskandar with scientific studies in the discipline of archealogy and history should be done in order to establish the validity of this notable character moreover to retain his high reputation in the Malay World.

\section{References}

Ahmad, A. S. (2013). Sulalatus Salatin (Sejarah Melayu). Kuala Lumpur: Dewan Bahasa dan Pustaka.

Braginsky, V. I. (1993). The System of Classical Malay Literature. Leiden: Koninklijk Voor Taal, Landen Volkenkunde.

Braginsky, V. I. (2000). Tajus Salatin ('The Crown of Sultan') of Bukhari al-Jauhari as as Cononical Work and an Attempt to Create a Malay Literary Canon. In. Smyth, D. (Ed.) The Conon in Southeast Asia Literature. Surrey: Curzon Press.

Brakel. (1970). Persian Influence on Malay Literature. Abr-Nahrain, 9: 206-221.

Embong, F. (1982). Beberapa Aspek dalam Kitab Taj us Salatin. Bangi: Penerbit Universiti Kebangsaan Malaysia.

Hassan, H. (2001). Sastera Epik: Hikayat Iskandar Zulkarnain. Monograf Bahasa, Sastera dan Budaya Melayu Bahasa Wahana IImu. Serdang: Penerbit Universiti Putra Malaysia.

Hamid, I. (1987). Perkembangan Kesusasteraan Melayu Lama. Selangor: Longman Malaysia Sdn. Bhd.

Harun, J. (2003). Pemikiran Adab Ketatanegaraan Kesultanan Melayu. Kuala Lumpur: Perpustakaan Negara Malaysia.

Harun, J. (2006). Bustan al-Salatin: Buku Sejarah dan Panduan Adab Pentadbiran Kesultanan Melayu. In. Rogayah A. Hamid. Kesultanan Melayu. Kuala Lumpur: Dewan Bahasa dan Pustaka.

Harun, J. (2006). Sahibul Kitab Sultan Zainal Abidin: Adab Ketatanegaraan Kesultanan Terengganu. In. Rogayah A. Hamid. Kesultanan Melayu Terengganu. Kuala Lumpur: Dewan Bahasa dan Pustaka.

Harun, Y. (2009). Bustan al-Salatin (The Garden of Kings): A Malay Mirror for Rules. Pulau Pinang: Penerbit Universiti Sains Malaysia.

Keempat, K. D. E. (2007). Kuala Lumpur: Dewan Bahasa dan Pustaka.

Hussain, K. (1966). Taj Us Salatin. Kuala Lumpur: Dewan Bahasa dan Pustaka.

Hussain, K. (2015). Hikayat Iskandar Zulkarnain. Kuala Lumpur: Dewan Bahasa dan Pustaka. 
INTERNATIONAL JOURNAL OF ACADEMIC RESEARCH IN BUSINESS AND SOCIAL SCIENCES

Vol. 9, No. 5, May, 2019, E-ISSN: 2222-6990 @ 2019 HRMARS

Harris, Muammar, K. A. (2001). Ilmu Ketatanegaraan Melayu Abad ke-19: Kajian Terhadap Karya, R. A.H., Sari, 29(1): 79-101.

Marrisson, G. E. (1955). Persian Infuence in Malay Life (1280-1650). Journal of the Malaysians Branch of the Royal Asiatic Society 28: 52-69.

Othman, M. A. (1983). The Sultanate as the Basis for Malay Political and Cultural Identity from a Historical Perspective. Sari 1(2): 161-174.

Abdullah, M. T. (1993). "The Islamic Political Tradition in Malay" DIm. Anthony Reid (Ed.) The Making of an Islamic Political Discourse in Southeast Asia. Monash Paper on Southeast Asia. Monash University. Australia.

Ismail, M. Z, \& Abdullah, W. S. W. (Ed.). (2012). Adab dan Peradaban: Karya Pengi'tirafan Syed Mohammad Naquid Al Attas. Kuala Lumpur: MPH Group Publishing.

Jamian, M. N., Yuszaidy, M., Ghaddafi, M., Yusmilayati. (2017). Keadilan Teras Kepimpinan Raja-Raja Melayu: Dari Era Tradisi Ke Kontemporari. Jurnal Melayu, 16 (1): 63-81.

Ab. Aziz, N. A. \& Jamian, M. N. (2016). Akhlak Pemimpin dan Hikayat Iskandar Zulkarnain: Satu Analisis Pendekatan Adab. Jurnal Melayu, 15 (1) : 50-66.

Hamdan, R. \& Sujud, A. (2017). Customs (Adab) Of Governance as Depicted In Traditional Malay Literature. Man in India, 97 (26): 199-213.

Hamdan, R., \& Sujud, Aa. (2019). Guidance Behind Criticisms: The Good Parenting as Portrayed in the First Malay Autobiography. Asian Social Science, 15 (2), 116-123, doi:10.5539/ass.v15n2p116.

Rani, R. M. (2013). Sifat dan Peranan Raja dan Pembesar dalam Naskah Hukum Kanun Pahang. Universiti Putra Malaysia, Serdang, Selangor.

Kelantan, S. O. (2007) Oktober. Dzulqarnain Bukan Alexander the Great. Dewan Sastera, 30-31.

Bakar, S. A. (1996). Sastera Islam Dalam Peradaban Ummah. Simposium Serantau Sastera Islam. Brunei: Dewan Bahasa dan Pustaka.

Nordin, S. Rul-A. (2012). Pemikiran Politik Islam di Acheh pada Abad Ke 17 M: Kajian Perbandingan Antara Kitab Taj Us-Salatin, Sulalah Al-Salatin dan Bustan Al-Salatin. Tesis Doktor Falsafah. Universiti Kebangsaan Malaysia. Bangi, Selangor.

Salleh, S. H. H. (Ed.). (1992). Bustan al-Salatin. Kuala Lumpur: Dewan Bahasa dan Pustaka.

Salleh, S. H. H. (2009). Kelopak Pemikiran Sastera Melayu. Bangi: Universiti Kebangsaan Malaysia.

Salleh, S. H. H. (2010). Malay Literature of the 19th Century. Kuala Lumpur: Institut Terjemahan Nasional Malaysia Berhad.

Syed Muhammad Naquib Al Attas. (1993). Islam Dan Sekularisme. Bandung: Indonesia: Institut Pemikiran Islam dan Pembangunan Insan.

Al-Attas, S. M. N. (2001). Risalah Untuk Kaum Muslimin. Kuala Lumpur: Institut Antarabangsa Pemikiran dan Tamadun Islam (ISTAC).

Terjemahan Al-Quran Al-Karim. (2015). Kuala Lumpur: Percetakan Zafar Sdn.Bhd.

Boa, W. Y. (2009). Diplomacy: Theory and Practice in Islam. Kuala Lumpur: Universiti Islam Antarabangsa. 